Doc. dr. sc. Henrik-Riko Held

Pravni fakultet Sveučilišta u Zagrebu ${ }^{1}$

\title{
KONDIKCIJSKI ZAHTJEVI I TURPITUDO U RIMSKOM PRAVU
}

UDK: 34 (37)

DOI: $10.31141 /$ zrpfs.2019.56.134.945

Izvorni znanstveni rad

Primljeno: 1. VIII. 2019.

Autor u radu analizira kondikcijske zahtjeve u rimskom pravu u situacijama u kojima je na određeni način postojala turpitudo, odnosno nemoralnost. U tu svrhu najprije obrađuje kondikcijske zahtjeve u sva tri rimska postupovna oblika, legisakcijskom postupku per condictionem, formularnoj condictio te različitim condictiones postklasičnog i Justinijanovog prava u kognicijskom, odnosno ekstraordinarnom postupku. Zatim se iznosi problematika značenja koje su termini turpitudo i turpis imali u rimskom pravu. Središnji dio rada jest analiza izvora, u kojoj se autor posebno bavi tipologijom slučajeva kondiciranja ob turpem rem, odnosno analizira condictio ob turpem (vel iniustam) causam u Justinijanovoj kodifikaciji. Analizirajući literaturu o predmetnoj problematici, naposljetku daje reinterpretaciju funkcija kondiciranja ob turpem rem u rimskom pravu, uz sugeriranje mogućeg objašnjenja njenog podrijetla te posljedično položaja i važnosti u općem rimskom kondikcijskom sustavu.

Ključne riječi: kondikcijski zahtjevi, condictio, turpitudo, condictio ob turpem vel iniustam causam, rimsko pravo

\section{UVOD}

U radu se analizira jedan od slučajeva kondiciranja u rimskom pravu, odnosno jedan slučaj korištenja kondikcijskog zahtjeva (condictio). Riječ je o kondiciranju, odnosno zahtijevanju predane stvari ili predanog novca natrag, ako je do predaje došlo radi neke svrhe (causa finalis) koja se smatra nemoralnom, to jest ako je do predaje došlo na temelju (causa efficiens) koji se smatra nemoralnim. ${ }^{2}$ U Justinijanovoj kodifikaciji ovaj slučaj poznat je pod nazivom condictio ob turpem (vel iniustam)

\footnotetext{
1 Henrik-Riko Held, Pravni fakultet Sveučilišta u Zagrebu,Trg Republike Hrvatske 14, 10000 Zagreb, hheld@pravo.hr

2 Dihotomija između dviju različitih vrsta uzroka, na latinskom causa efficiens i causa finalis, koja potječe od Aristotelovih poznatih četiriju uzroka (Aristotel, Metafizika V, 1013a (preuzeto iz Tredennick, 1989), o čemu više u Falcon, 2012), ovdje je s obzirom na vremenski i konceptualni kontekst rasprave najprikladnija. Ta dihotomija vezana je za terminološko i konceptualno razlikovanje predaje ob causam ili ob rem, o čemu će biti nešto više riječi kasnije u radu. U svakom slučaju valja istaknuti kako se u ovome radu ne ulazi u suvremenu problematiku razlikovanja pravne osnove i pravnog razloga, takozvane kauze obveze, subjektivne i objektivne osnove, itd. (o tomu Klarić i Vedriš, 2006, str. 148 sqq. te iscrpnije i poredbenopravno Nikšić, 2012).
} 
causam, i u tom obliku je bio predmet obrade srednjovjekovnih civilista i recepcije rimskog prava, a i danas se taj termin i koncept može pronaći u znanstvenim analizama suvremenog privatnog prava, odnosno u sudskoj praksi. ${ }^{3}$ Međutim, kako će se vidjeti iz analize koja slijedi, kondiciranje ob turpem rem, odnosno ob turpem causam, razvilo se još u klasičnom pravu u specifičnim okolnostima formularnog postupka, nasuprot kognicijskog (ekstraordinarnog) postupka Justinijanovog prava. Uz to, određeni temelji za razvoj u klasičnom pravu postojali su i u ranijim razdobljima rimskog prava, za vrijeme primjene legisakcijskog postupka, odnosno, konkretnije za ovu analizu, postupka legis actio per condictionem.

Zbog svega navedenog u radu se najprije ukratko analizira postupovno uređenje kondikcijskih zahtjeva unutar tri različita postupka u rimskom pravu, dakle legisakcijskom, formularnom i kognicijskom, odnosno ekstraordinarnom postupku. Nakon toga obrađuje se problematika sadržaja i značenja koje su u rimskom pravu imali termini turpitudo, odnosno res ili causa turpis, to jest problematika standarda nemoralnosti koji su utjecali na oblikovanje tog koncepta i njegovu formulaciju u pravnom kontekstu. U sljedećem, središnjem dijelu rada, pobliže se analiziraju slučajevi primjene kondiciranja ob turpem (vel iniustam) rem, odnosno causam u Justinijanovoj kodifikaciji. Tu se nastoji na temelju dokumentiranih slučajeva uporabe tog sredstva, uz kritičku analizu, rasvijetliti koja je bila njegova svrha u klasičnom i postklasičnom pravu te posljedično i u naknadnom razvoju. Uz to, cilj je utvrditi na koji način se taj slučaj kondiciranja uklapa u opći klasični kondikcijski sustav te u samo podrijetlo kondikcijskih zahtjeva u legisakcijskom postupku. Time se nadamo dati doprinos uobičajenom shvaćanju kondikcijskih zahtjeva ob turpem (vel iniustam) rem i causam, odnosno stjecanja (obogaćenja) na temelju nemoralne ili nedopuštene osnove.

\section{KONDIKCIJSKI ZAHTJEVI U RAZLIČITIM POSTUPOVNIM UREĐENJIMA RIMSKOGA PRAVA}

Iz sasvim razumljivih razloga, iz perspektive suvremenog prava, pa i na pojednostavljenoj udžbeničkoj razini rimskoga prava, kondikcijski zahtjevi se uglavnom promatraju kroz njihov oblik kakav se razvio u klasičnom pravu te kakav je bio prilagođen i unesen u Justinijanovu kodifikaciju. To je bez sumnje najvažniji pojavni oblik rimskih kondikcijskih zahtjeva, koji je kao takav bio predmet srednjovjekovne analize i naknadne recepcije. Međutim, u svrhu predmetne analize važno je istaknuti bitno različite postupovne okvire u kojima su se odvijali kondikcijski zahtjevi u rimskom pravu, te nadovezane posljedice za koncipiranje slučajeva njihove primjene koji uključuju turpitudo. To znači da treba razlikovati ostvarivanje kondikcijskih zahtjeva u tri različita rimska postupovna sustava. Kako

3 Vidi Zimmerman, 1992, str. 862 sqq., s iscrpnim uputama na izvore i daljnju literaturu. U domaćoj literaturi condictio ob turpem vel iniustam causam, odnosno stjecanje na temelju nemoralne ili nedopuštene osnove, predmet je analize u kontekstu suvremenog zakonodavstva i sudske prakse u Karlović i Held, 2011. 
će se vidjeti iz analize koja slijedi, u legisakcijskom postupku je postojala posebna legis actio per condictionem. U formularnom postupku je pak postojala jedinstvena formula za sve kondikcijske zahtjeve, ali i niz različitih slučajeva njihove primjene. Naposljetku, u kognicijskom (ekstraordinarnom) postupku zaštita se odvijala unutar općeg sudskog postupka, uz zadržanu klasičnu kondikcijsku nomenklaturu.

Legisakcijski postupak je bio najstariji postupak rimskoga prava, koji se odvijao u više različitih oblika. ${ }^{4}$ Jedan od tih oblika bila je i legis actio per condictionem, kao jedna od najmlađih i najjednostavnijih legisakcija. ${ }^{5}$ Njena glavna i definirajuća karakteristika bila je apstraktnost, što znači da se u formulaciji zahtjeva unutar legisakcije per condictionem nije navodio pravni temelj obveze nego samo činjenica postojanja dugovanja, dare oportere (Gai. Inst. IV, 17b-20; cf. Kaser i Hackl, 1996, str. 111; Zimmerman, 1992, str. 835). Bez ulaženja u detalje nepotrebne u predmetnoj raspravi, ovdje se može istaknuti samo kako je u literaturi općeprihvaćen opseg primjene legisakcije per condictionem, te je on obuhvaćao mutuum (zajam), indebiti solutio (plaćanje neduga), stipulatio, expensilatio, i furtum (krađu) (Kaser i Hackl, 1996, str. 112). Već na prvi pogled vidljivo je kako su gotovo svi ti slučajevi konceptualno povezani. Mutuum i indebiti solutio su zapravo srodni načini nastanka obveze, jer je u oba slučaja riječ o predaji novca ili drugih zamjenjivih stvari drugoj osobi u vlasništvo, uz razliku što je mutuum način zasnivanja nove obveze, a indebiti solutio je pokušaj dužnika da izvrši postojeću obvezu (Gai. Inst. III, 91). Stipulatio je usmeni a expensilatio pisani oblik zasnivanja apstraktne obveze na plaćanje određenog iznosa novca ili drugih zamjenjivih stvari. Pritom su oba posla često zaključivani nadovezano na zajam, čime su se i oni konceptualno uklopili u predmetni kontekst ( $c f$. Zimmerman, 1992, str. 836).

Furtum, odnosno krađa, naizgled odudara od ostalih slučajeva, te se kondiciranje s tim u vezi još u rimskom pravu činilo kao iznimka uvjetovana potrebom opterećivanja mrskih lopova sa što više tužbi (Gai. Inst. IV, 4; $c f$. Liebs, 1972, str. 86 sqq.). Podrobna analiza može se naći drugdje (Pika, 1988). Ovdje je dovoljno istaknuti kako je u literaturi utvrđena prikladnost kondiciranja čak i za slučaj krađe, s obzirom na očitu činjenicu postojanja obveze povrata ukradene stvari, dare oportere, što je temelj svih kondikcijskih zahtjeva (Zimmerman, 1992, str. 836). Međutim, time je svakako u jednom slučaju primjene legisakcije per condictionem, dakle izvornog i najstarijeg oblika u kojem su se utuživali kondikcijski zahtjevi, utvrđeno postojanje jednog društveno nepoželjnog ponašanja, štoviše delikta, a samim time u svakom slučaju i nemoralnog čina. Osim toga, u literaturi postoji teorija po kojoj se u samim počecima razvoja zajma (mutuum) neizvršavanje obveze zajmoprimca, odnosno izostanak povrata pozajmljenog iznosa, tretiralo kao delikt

4 Općenito više o legisakcijskom postupku u Kaser i Hackl, 1996, str. 34 sqq., te nešto manje opširno Guarino, 2001, str. 168 sqq.; Jörs, Kunkel i Wenger, 1987, str. 506 sqq. Za enciklopedijske reference vidi Paulus, 1999, str. 22 sqq.; Talamanca, 1987, str. 4 sqq.; Mayer-Maly, 1969, str. 546 sq.; Betti, 1966, str. 1104 sq.; Weiss, 1925, str. 1838 sqq. Za monografije o predmetnoj problematici vidi Albanese, 1987; Cannata, 1980; Pugliese, 1961. Problem samog nastanka ovog postupka predmet je analize u Nicosia, 1986.

5 Uz literaturu iz prethodne bilješke, legis actio per condictionem, odnosno preciznije problem podrijetla tog postupka analizira se u domaćoj literaturi podrobnije u Held, 2017. 
(Schwarz, 1952, str. 278 sqq.; Raber, 1969, str. 1502; Cannata, 1970, str. 57; Kaser, 1971, str. 593). Naime, za pozajmljene stvari ili pozajmljeni novac na neki način se smatralo da su i dalje u vlasništvu zajmodavca, otkuda potječe i naziv aes alienum za pozajmljeni novac (Schwarz, 1952, str. 278; Kaser, 1971, str. 593). Na temelju svega navedenog može se zaključiti kako su određene društveno neprihvatljive pojave, čak i delikti ili deliktima srodne pojave, čime ih se u svakom slučaju može smatrati nemoralnima, bili u samim temeljima te u osnovnom opsegu primjene izvornog oblika kondikcijske zaštite, odnosno legisakcije per condictionem.

Formularni postupak bio je glavni modus procedendi u pretklasičnom i klasičnom razdoblju rimskog prava, ${ }^{6}$ te se daljnji razvoj kondikcijskih zahtjeva razmatra u njegovim okvirima. $U$ trenutnoj analizi važno je naglasiti kako je $u$ ostvarivanju kondikcijskih zahtjeva u formularnom postupku postojala jedinstvena formula za sve kondikcijske zahtjeve, uz manje razlike vezane jedino za to traži li se iznos novca ili neka druga stvar (Schwarz, 1952, str. 46; Raber, 1964, str. 1273; Buckland i Stein, 1966, str. 682; Kaser, 1971, str. 594; Zimmerman, 1992, str. 839; $c f$. Mantovani, 1999, str. 48 sq.). Međutim, u praksi su se uobičajili najčešći slučajevi koji se zbog toga smatraju tipičnim područjem primjene tužbe condictio u klasičnom pravu. Tu je najprije bila riječ o već navedenim slučajevima koje je pokrivala legis actio per condictionem. Osim njih, među dodatne valja istaknuti traženje povrata za slučaj kad izvorni temelj predaje naknadno otpadne (takozvana causa finita), kad se svrha radi koje je plaćanje izvršeno ne ostvari (datio ob rem, odnosno ob causam), te naposljetku slučaj predaje stvari u svrhu koja se smatrala nemoralnom (datio ob turpem rem, to jest ob turpem causam) (cf. Kaser, 1971, str. 594 sqq.; Zimmerman, 1992, str. 838 sqq.). Posljednji slučaj predmet je posebne detaljne analize kasnije u tekstu.

Naposljetku, u kognicijskom ili ekstraordinarnom postupku postklasičnog i Justinijanovog prava dogodio se posljednji stadij razvoja kondikcijskih zahtjeva u rimskom pravu. ${ }^{7}$ Pojedinačni slučajevi primjene klasične condictio, temeljeni na izvornom opsegu legisakcije per condictionem te proširenjem na određene srodne slučajeve u klasičnom pravu, sad su postali zasebne kategorije (Zimmerman, 1992, str. 838 sq.). Naime, kako je ranije razjašnjeno, u formularnom postupku za kondikcijsku zaštitu je bilo predviđeno jedinstveno sredstvo sa zasebnom formulom (condictio), uz više različitih slučajeva njegove primjene. Napuštanjem formularnog sustava, u kognicijskom postupku condictio više nema nikakvo postupovno značenje, a pojedini slučajevi primjene tog sredstva u formularnom postupku sad postaju elementi materijalnog prava (Zimmerman, 1992, str. 839). U

6 Detaljnije o formularnom postupku u Kaser i Hackl, 1996, str. 151 sqq., manje opširno Guarino, 2001, str. 183 sqq.; Jörs et al., 1987, str. 524 sqq. Enciklopedijske reference mogu se naći u Talamanca, 1987, str. 24 sqq.; Betti, 1966, str. 1106 sqq. Za monografiju posvećenu specifično ovom postupku vidi Cannata 1982. Problematika nastanka ovog postupka posebno se analizira u Magdelain, 1991; Scherillo, 1969; Luzzatto, 1946.

Više o kognicijskom ili ekstraordinarnom postupku u Kaser i Hackl, 1996, str. 435 sqq., te manje opširno Guarino, 2001, str. 244 sqq.; Jörs et al., 1987, str. 555 sqq. Za enciklopedijsku referencu vidi Betti, 1966, str. 1113 sqq. Za monografije o postklasičnom kognicijskom postupku Justinijanovog prava vidi Simon, 1969; Provera, 1989. 
tom smislu se condictio indebiti, condictio ob causam finitam, condictio ob rem, itd. trebaju smatrati postklasičnim terminima i konceptima. ${ }^{8}$ Naravno, rečeno vrijedi i za condictio ob turpem (vel iniustam) causam, kao postklasičnu manifestaciju kondikcijskog zahtjeva koji uključuje turpitudo.

\section{TURPITUDO U RIMSKOM PRAVU}

Imenica turpitudo na latinskom jeziku označava ružnoću, neprikladnost, izobličenost i sl., čemu odgovara i pridjev turpis, kojim se opisuje nešto nakazno, prljavo, opsceno itd. (Lewis i Short, 1879, unosi turpitudo i turpis; Forcellini, 1940, str. 837; cf. za srednjovjekovni latinski Cange, 1887, str. 215). U skladu s ovako širokim poimanjem tih termina, u konkretnijem smislu oni se odnose na moralnu izopačenost, nemoralnost, odnosno suprotnost određenim vrijednostima uspostavljenima putem tradicije i običaja (Cic. off. III, 105; $c f$. Sachers, 1948, str. 1433). Standard ponašanja kojega turpitudo, odnosno određena radnja koja je turpis, narušava, jest takvo ponašanje za koje se može reći da je honestum, odnosno da je ono što spada u dobre običaje, boni mores (Kaser, 1940, str. 100; $f f$. Medicus, 1975, str. 1009; Gamauf, 2002, str. 927). Pritom valja naglasiti kako izvor morala kao relevantnog standarda ponašanja u predmetnom smislu jest tradicija, odnosno generacijsko prenošenje životnih praksi koje su smatraju društveno korisnima i dobrima, a ne određeni filozofski sistem (Kaser, 1940, str. 101). Postoji više termina kojima su se mogle opisati moralno problematične osobe i njihovo ponašanje, poput improbus, scelus, ignominia itd. (Kaser, 1940, str. 104 sqq.). Međutim, osim relativne učestalosti upravo termina turpitudo i turpis u izvorima (Kaser, 1940, str. 110 sqq.), ovdje su oni u središtu pažnje i zbog terminološke prisutnosti kod kondiciranja u klasičnom rimskom pravu.

U izvorima se mogu naći reference na takozvane actiones turpes, odnosno tužbe čiji je predmet bilo ponašanje karakterizirano kao turpis, primjerice actio furti, actio inuriarum, actio vi bonorum raptorum itd. (Sachers, 1948, str. 1434). Ta kategorizacija je najvjerojatnije postklasičnog podrijetla (Kaser, 1940, str. 110 sq.), te su se ove tužbe u bitnom dijelu podudarale s onima koje su bile actiones famosae (Sachers, 1948, str. 1434). Osim toga, određena zanimanja su uzrokovala turpitudo, pa su se tako kao personae turpes smatrali primjerice scaenicus (glumac), caupo (gostioničar), carnifex (mesar), monetarius (kovač novca), vispellio (kradljivac odjeće s mrtvih tijela), libitinarius (grobar), meretrix (prostitutka), gladijator itd. (Sachers, 1948, str. 1434). Naposljetku, određena djela su također uzrokovala turpitudo, na primjer sacrilegium facere (svetogrđe), hominem occidere (ubojstvo), podmićivanje suca itd. (Kaser, 1940, str. 112 sqq.). Od Augusta nadalje, turpitudo se sve više vezuje i uz pitanja seksualnog morala, s čim u vezi je izuzetno bitna lex Iulia de adulteriis iz 18. g. pr. Kr. temeljem koje turpitudo uzrokuju adulterium

8 Modelska problematika jedinstvene (monističke) ili raslojene (pluralističke) kondikcijske zaštite u rimskom pravu, ali i u njegovoj srednjovjekovnoj obradi te naknadnoj recepciji, glavna je tematska i konceptualna okosnica doktorata Held, 2015. 
(preljub), stuprum (opći naziv za seksualni nemoral), lenocinium (svodništvo) itd. (Schwarz, 1952, str. 178; više o navedenom zakonu Rotondi, 1962, str. 445 sqq.).

Općenito govoreći, sankcija bilo kakvog nemoralnog ponašanja u rimskom društvu je postojala od najranijih razdoblja (Kaser, 1940, str. 95), uz to što se vremenom mijenjala sfera u kojoj se to sankcioniranje odvijalo. Naime, u ranijim razdobljima za brigu o uzdržavanju običajnog morala bila je zadužena posebna magistratura, cenzori (Kaser, 1939, str. 52; Kaser, 1940, str. 95; više o cenzorima u Kaser, 1971, str. 62 i bilj. 17). S nestankom rimske Republike, gašenjem cenzure i usponom carstva, u općoj atmosferi propadanja starih rimskih moralnih standarda, moral postaje sve više i više pitanje carskog zakonodavstva te jurisprudencije (Kaser, 1940, str. 96). U tom kontekstu su i učenja određenih filozofskih škola kao i određeni kršćanski koncepti svojstveni kasnijem carskom zakonodavstvu prodrli u određivanje i sankcioniranje nemoralnog ponašanja (Kaser, 1940, str. 102). Time je ono postalo predmet ne samo običajne, nego i konkretne pravne regulacije. Ali u svakom slučaju, kako se može vidjeti iz analize u nastavku teksta, sadržaj moralnih standarda je ostao otprilike podjednak u svim tim razdobljima, samo se mijenjao njihov vidljivi izvor, od uobičajenosti u narodu do zakonodavnog ustanovljenja s najviše razine.

U tom smislu, turpitudo sama po sebi je uzrokovala određene pravne posljedice, recimo u statusnom smislu umanjenja časti, odnosno pravne sposobnosti ili valjanosti pravnih poslova u kojima je na neki način bila uključena (Eisner i Horvat, 1948, str. 125; Kaser 1940, str. 112 sqq.; Kaser, 1977). Koje su bile pravne posljedice kad je kod predaje (datio) novca ili neke druge stvari postojala res (svrha ili causa finalis) ili causa (temelj ili causa efficiens) za koje se smatralo da su turpis, pobliže se analizira u tekstu koji slijedi.

\section{OB TURPEM REM CONDICERE U JUSTINIJANOVOJ KODIFIKACIJI}

\subsection{Terminologija}

Prije prelaska na izravnu analizu izvora potrebno je istaknuti tri relevantne terminološke napomene. Najprije, u nastavku na navedeno u dijelu rada posvećenom kondikcijskim zahtjevima u različitim postupovnim uređenjima rimskoga prava, termin condictio ob turpem (vel iniustam) causam odnosno rem, ako se poima u smislu zasebnog pravnog sredstva, jest svakako neklasičan izraz, svojstven kognicijskom postupku i Justinijanovoj kodifikaciji. Naime, kako je napomenuto ranije, klasična condictio bila je jedinstveno postupovno sredstvo, a imala je različite instance primjene koji su u kognicijskom postupku i Justinijanovom pravu postali zasebni materijalnopravni instituti. Zbog toga se u ovom radu termin condictio ob turpem (vel iniustam) causam ili rem ne koristi kao općeniti naziv za kondikcijski zahtjev u vezi kojeg postoji turpitudo, već se koristi postupovno a time i konceptualno neutralniji termin ob turpem rem condicere ili kondiciranje ob turpem rem. 
Nadalje valja napomenuti kako je još u izvorima postojalo razlikovanje predaje stvari (datio) ob rem, odnosno radi neke određene svrhe (causa finalis) te ob causam, ili na određenom postojećem temelju (causa efficiens) (D. 12, 6, 52 (Pomp. 27 ad q. muc.)). S tim u vezi bi se terminološki i sadržajno moglo razlikovati i kondiciranje $o b$ turpem rem i ob turpem causam. Temeljita rasprava na tu temu već postoji u literaturi, pa nema potrebe za posebnom analizom (Schwarz, 1952, str. 117 sqq.; cf. Kaser, 1971, str. 597 sq.; Liebs, 1978, str. 698; Liebs, 1986, str. 172 sqq., sve s uputama na daljnju literaturu). Dovoljno je istaknuti kako navedena podjela nije bila dosljedno korištena ni u izvorima, te se terminološka diskrepancija u literaturi vezuje i uz razlike između dviju rimskih pravnih škola, Sabinovaca i Prokulovaca (Liebs, 1978, str. 698). U svakom slučaju, nije uopće izvjesno strogo značenjsko razlikovanje između datio ob rem i datio ob causam u klasičnom pravu (Kaser, 1971, str. 597 bilj. 42). Uz to, općenito korištenje sintagme $o b$ rem smatra se karakterističnijom za ranije klasično razdoblje, a ob causam za kasnoklasične, odnosno posljednje klasične autore, poput Ulpijana (Liebs, 1986, str. 173). S obzirom na navedeno, u ovom radu se koristi sintagma ob (turpem) rem kao primjerenija klasičnom pravu, bez ikakvog opredjeljivanja vezanog za to odnosi li se predaja (datio) na neku svrhu (causa finalis) ili se veže za određeni postojeći temelj (causa efficiens).

Naposljetku, u izvorima se u predmetnom kontekstu osim pridjeva turpis pojavljuje i pridjev iniustus, pa je tako cijeli peti titul dvanaeste knjige Justinijanovih Digesta naslovljen De condictione ob turpem vel iniustam causam. Ovdje valja napomenuti kako se dodavanjem termina iniusta nije puno proširilo područje primjene ovog sredstva (Zimmerman, 1992, str. 845). Stoviše, poznat je samo jedan slučaj koji se odnosi na kondiciranje stvari koja je bila predana $o b$ iniustam causam, i to iz D. 12, 5, 6 (Ulp. 18 ad sab.), u kojem je riječ o općenitom dopuštanju kondiciranja kad se određena stvar nalazi kod nekoga ex iniusta causa. Inače, kondiciranje ex iniusta causa spominje u drukčijem kontekstu i Justinijanov Codex, pa je tako titul C. 4, 9 naslovljen De condictione ex lege et sine causa vel iniusta causa. Međutim, ni tu nema nekog slučaja koji bi se odnosio specifično na kondiciranje ex iniusta causa. ${ }^{9}$ Dodavanje pridjeva iniustus bi se stoga moglo objasniti postklasičnom i Justinijanovom tendencijom postupnog približavanja običajnih i zakonskih, odnosno carskih, standarda nemoralnosti (cf. Kaser, 1940,

9 Ovaj titul sastoji se od samo četiri konstitucije. Pritom nije razjašnjeno koja od njih se odnosi na koji slučaj kondiciranja iz naslova titula. Prva konstitucija, C. 4, 9, 1 (Imp. Diocletianus et Maximianus), tiče se specifičnog slučaja dugovanja fisku, gdje se utvrđuje preferencija tog duga u odnosu na druge dugove. Stoga bi se to moglo svrstati pod svojevrsnu condictio ex lege (o tomu Kaser, 1975, str. 424). Druga konstitucija, C. 4, 9, 2 (Imp. Diocletianus et Maximianus) vezana je za slučajeve koji su u kontekstu klasičnog prava bili označeni kao condictio liberationis (o tomu Kaser, 1971, str. 598 sq.; Zimmerman, 1992, str. 856), kao i četvrta konstitucija, C. 4, 9, 4 (Imp. Diocletianus et Maximianus). One se mogu svrstati pod općenitu condictio sine causa, s obzirom na analogne slučajeve koje je Justinijan svrstao pod titul D. 12, 7 De condictione sine causa u Digesta. Treća konstitucija, C. 4, 9, 3 (Imp. Diocletianus et Maximianus) tiče se kondiciranja stvari koje su trebale biti predmet vindiciranja kao plodovi glavne stvari, ali su u međuvremenu potrošene. Ovi raznoliki slučajevi bi u Justinijanovoj klasifikaciji bili najbliži kondikciji sine causa kao kategoriji koja obuhvaća razne slučajeve kondiciranja koji ne mogu biti svrstani drugdje (o tomu Zimmerman, 1992, str. 871 sqq.). Stoga pod titulom C. 4, 9 zapravo nema spomena o kondiciranju ex iniusta causa. U tom smislu je navedena sintagma relevantna više kao dodatni opis sadržaja predmetnog titula nego kao konkretni primjer kondiciranja u određenom slučaju. 
str. 147; Kaser, 1977, str. 72 bilj. 12). Drugim riječima, moglo bi se reći kako se u vezivanju standarda nemoralnosti uz protupravnost manifestira postklasična tendencija koncentracije zakondavne ovlasti u rukama cara ( $c f$. o tomu Kaser, 1967, str. 217 sqq.). Zbog svega navedenog u ovom radu se kao najprikladniji termin za većinu dokumentiranih slučajeva upotrebe kondikcijskog zahtjeva za slučajeve u kojima je postojala turpitudo koristi upravo sintagma ob turpem rem condicere, odnosno kondiciranje ob turpem rem.

\subsection{Tipologija slučajeva kondiciranja ob turpem rem}

U ovom dijelu rada analiziraju se izvori koji svjedoče o kondiciranju ob turpem rem. Riječ je o izvorima Justinijanovoga prava, dakle izvacima koje sadrže Digesta i Codex. Pritom predmet analize nije problematiziranje klasičnosti fragmenata iz Digesta, koji se uzimaju kao u bitnom dijelu autentični ( $c f$. Schwarz, 1952, str. 169 sqq.; Kaser, 1971, str. 597 sq.). Okosnica analize jesu pojedini slučajevi ob turpem rem kondiciranja u klasičnom i postklasičnom pravu kao temelj za zaključke o njihovom podrijetlu i položaju u općem rimskom kondikcijskom sustavu.

Poseban titul unutar Digesta posvećen je kondiciranju ob rem turpem, i to D. 12, 5 , naslovljen, kako je već istaknutno ranije, De condictione ob turpem vel iniustam causam. Codex također sadrži poseban titul s navedenom problematikom, C. 4, 7, naslovljen De condictione ob turpem causam. Osim toga, postoji i nekoliko primjera kondiciranja ob turpem rem izvan navedenih titula, koji će također biti analizirani u tekstu koji slijedi. U navedenim izvorima sadržano je više različitih slučajeva kondiciranja kod kojih je na neki način bila uključena turpitudo. Ovdje će se, kao temelj za daljnju raspravu, navedeni slučajevi podijeliti u dvije skupine, najprije onu skupinu u kojoj je povrat predanog novca ili drugih stvari dopušten, a zatim onu skupinu u kojoj to nije dopušteno.

Tako je po D. 12, 5, 2, pr. (Ulp. 26 ad ed.) povrat predanog novca ili drugih stvari bio dopušten u slučaju kad je do predaje došlo zbog toga što je stjecatelj tražio predaju pod prijetnjom počinjenja određenog nedjela ako do predaje ne dođe. Po navedenom fragmentu u takva djela spadaju sacrilegium (svetogrđe, poput krađe posvećenih stvari iz hramova i sl.), furtum (krađa) i ubojstvo. Sasvim je jasno kako se navedena djela mogu smatrati nemoralnima, ali s obzirom na činjenicu da je povrat moguć čak i ako ona ne bi bila počinjena, nemoralnost u navedenim slučajevima jest ujedno i prijetnja njihovog počinjenja ako ne dođe do predaje, što je u svojoj biti pretorski delikt metus (o tomu više u Kaser, 1971, str. 243 sqq.). Ista logika postoji u dopuštanju povrata kad je stjecatelj tražio predaju tvrdeći da će u protivnom počiniti delikt iniuria (D. 12, 5, 4, 2 (Ulp. 26 ad ed.)). Nadalje, ako bi depozitar tražio od deponenta određenu predaju prije povrata deponirane stvari, što je inače bio obvezan napraviti potpuno besplatno ( $c f$. o tomu Kaser, 1971, str. 534 sqq.; Zimmerman, 1992, str. 205 sqq.), to se također moglo kondicirati (D. 12, 5, 2, 1 (Ulp. 26 ad ed.)). Isto vrijedi ako bi komodatar prije povrata posuđene stvari tražio predaju određene stvari ili novca od komodanta (D. 12, 5, 9, pr. (Paul. 5 ad 
plaut.)), a to je također komodatar bio obvezan učiniti bez ikakve naplate ( $c f$. o tomu Kaser, 1971, str. 543 sq.; Zimmerman, 1992, str. 188 sqq.). Slična situacija, samo s tutorom kao depozitarom ili komodatarom a pupilovim ocem kao deponentom ili depozitarom, može se naći i izvan ovog titula, u D. 27, 3, 5 (Ulp. 43 ad sab.) (više o tuteli u Kaser, 1971, str. 352 sqq.). Nadalje, ako bi rob predao novac nekoj osobi kako ga ona ne bi izdala gospodaru, gospodar je mogao tražiti isplaćeno natrag kondikcijom, što je također mogao ako bi došlo do isplate lopovu, robu bjeguncu ili nekom od njihovih pomoćnika radi toga da izdaju jedan drugog (D. 12, 5, 4, 4 (Ulp. 26 ad ed.)). Također, kondiciranje je bilo moguće ako bi došlo do određene isplate radi predaje nečega što se duguje po oporuci ili na temelju stipulacije (D. 12, 5, 9, 1 (Paul. 5 ad plaut.)). Povrat je bio moguć i ako bi rob platio nekomu da ne otkrije činjenicu kako je nešto ukrao svojem gospodaru, bez obzira na to je li došlo do otkrivanja ili ne (D. 12, 5, 5 (Iul. 3 ad urs. ferocem.), $c f$. o tomu Daube, 1986). Ako bi do isplate novca došlo povodom stipulacije koja je bila izvedena pod prisilom, također se dopuštalo kondiciranje (D. 12, 5, 7 (Pomp. $22 \mathrm{ad} \mathrm{sab.)).}$ Nemoralan razlog (inhonesta causa) sklapanja zaruka omogućavao je kondiciranje stvari predane radi tih istih zaruka (D. 19, 5, 17, 5 (Ulp. 28 ad ed.)).

Justinijanov Codex ima nekolicinu relevantnih primjera. Tako primjerice u C. 7, 4, 3 (Imp. Diocletianus et Maximianus) carska kancelarija vojniku Dizonu pojašnjava kako može kondicirati natrag iznos kojeg je od njega tražila i dobila osoba zadužena za regrutaciju, a svrha predaje je bila kako on ne bi bio regrutiran. Ista carska kancelarija odredila je da novac predan lopovu kako bi vratio ukradenu stvar može biti kondiciran (C. 4, 7,6). Također, od istih careva dolazi i odluka po kojoj osoba koja je nekomu odvela stoku te zatim tražila i dobila novac radi njenog povrata može biti tužena kondikcijom (C. 4, 7, 7).

U drugu skupinu mogu se svrstati slučajevi u kojima na određeni način postoji turpitudo ali gdje kondiciranje nije dopušteno. Tako D. 12, 5, 2, 2 (Ulp. 26 ad ed.) i D. 12, 5, 3 (Paul. 10 ad sab.) onemogućuju kondiciranje ako je izvršena isplata sucu radi donošenja željene presude. Ako je nešto predano radi nemoralnog seksualnog odnosa (stuprum), odnosno ako je određena osoba zatečena u preljubu (adulterium) pa izvrši predaju da ne bi bila izdana (D. 12, 5, 4, pr. (Ulp. 26 ad ed.)), povrat također nije bio dopušten. Slično tomu, ako lopov izvrši isplatu tako da ne bi bio izdan nije moguće kondiciranje plaćenoga natrag (D. 12, 5, 4, 1 (Ulp. 26 ad ed.)). Isplata prostitutki (meretrix) nije se mogla kondicirati natrag, uz domišljato objašnjenje kako je tu platitelj nemoralan, a dok je zanimanje prostitutke svakako nemoralno, njeno primanje isplate samo po sebi nije (D. 12, 5, 4, 3 (Ulp. 26 ad ed.), $c f$. o tomu Sturm, 1986). Ako je došlo do stipulacijskog obvezivanja na temelju koji se smatra nemoralnim, također nije bio moguć povrat (D. 12, 5, 8 (Paul. 3 quaest.)).

U skladu s posljednjim navedenim slučajem, Codex također navodi kako isplatu kojoj je temelj stipulatio, odnosno cautio, nije moguće kondicirati ako je temelj predmetne stipulacije nemoralan (C. 4, 7, 1 (Imp. Antoninus)). Kao konkretni primjer navodi se stipuliranje i plaćanje vezano za svodništvo (lenocinium) i prostituciju (C. 4, 7, 5, (Imp. Diocletianus et Maximianus)). U tipičnom duhu 
carskog prava, u jednom primjeru kao standard moralnosti navodi se disciplina temporum meorum, odnosno (moralna) disciplina carevog vremena (C. 4, 7, 2 (Imp. Antoninus)). Naposljetku, ako bi tutor ili kurator oženio svoju štićenicu, odnosno ako bi to učinio njegov sin, bez carskog dopuštenja, bilo kakav miraz predan u tu svrhu mogao je biti kondiciran (C. 5, 6, 7, (Imp. Diocletianus, Maximianus)).

\subsection{Opća funkcija kondiciranja ob turpem rem}

Ovdje se može postaviti pitanje koja je bila uloga i značenje kondiciranja $o b$ turpem rem u rimskom pravu i rimskom kondikcijskom i općem pravnom uređenju, odnosno koja je bila njegova funkcija. Uobičajeno objašnjenje u literaturi jest da je kondiciranje ob turpem rem zapravo samo varijacija ili iznimka od kondiciranja ob rem. Naime, kondiciranje ob rem, poznato i pod nazivima condictio ob rem dati, condictio ob causam datorum ili u Justinijanovoj kodifikaciji condictio causa dana causa non secuta, postoji kod predaje novca ili neke druge stvari radi određene svrhe koja se svojevremeno ne ostvari (cf. o tomu Kaser, 1971, str. 597; Chaudet, 1973; Kaser, 1975, str. 423; Zimmerman, 1992, str, 843 sq.). Za slučaj kad je predmetna svrha nemoralna, navodi se, kondiciranje je bilo moguće čak i kad se ona ostvari (D. 12, 5, 1, 2 (Paul. 10 ad sab.); cf. Honsell, 1974, str. 84; Liebs 1986, str. 174; Zimmerman 1992, str. 845). Drugim riječima, mogli bismo zaključiti kako je za ob turpem rem condicere zapravo sasvim svejedno ostvaruje li se svrha radi koje je nešto predano ili ne. Temelj za povrat jest postojanje nemoralnosti, turpitudo, u predmetnoj transakciji.

Takvom shvaćanju doprinose i temeljna pravila povrata koja se mogu iščitati u izvorima. Naime, povrat je moguć jedino ako postoji nemoralnost isključivo na strani stjecatelja (turpitudo accipientis), a ako postoji kod obje strane (turpitudo utriusque) ili samo na strani platitelja (turpitudo solius dantis), kondiciranje nije moguće ( $c f$. Zimmerman, 1992, str. 844 sqq.; terminologija je u bitnom preuzeta iz fragmenta D. 12, 5, 1, pr. (Paul. 10 ad sab.)). U tom smislu, temeljna funkcija uređenja kondiciranja ob turpem rem jest svojevrsna sankcija nemoralnosti. Rimski pravni sustav inače u tom pogledu nije bio sveobuhvatan i temeljit, primjerice na način da bi nemoralnost uvijek i ipso facto imala određene nepovoljne pravne posljedice. ${ }^{10}$ Zbog toga navedeno uređenje povrata ima višestruku funkciju. Najprije se sanira situacija kad je stjecatelj nemoralan, te on mora restituirati ono što je bilo predano platitelju. S druge strane, nema nikakve potrebe za zaštitom platitelja koji je sam nemoralan, a u slučaju kad su i platitelj i stjecatelj nemoralni, jednostavno nema potrebe da pravni sustav intervenira. Tu zapravo do izražaja dolazi pravilo po kojem je kod postojanja nemoralnosti i kod platitelja i kod stjecatelja bolji (pravni) položaj trenutačnog posjednika, što se u kasnijem razvoju izrazilo kao načelo in pari turpitudine melior est causa possidetis (o tomu cf. Honsell, 1974,

10 Primjerice, vlasništvo na novcu bi prelazilo čak i ako bi temelj prijelaza bio turpis (o tomu detaljno Kaser, 1961). Detaljno o nemoralnosti i utjecaju na pravne poslove u već spomenutima Kaser, 1939; Kaser, 1940; Kaser, 1977. 
str. 88 sqq.; Zimmerman, 1992, str. 846). Osim toga, navedena pravila djeluju i kao obeshrabrivanje nemoralnih transakcija u pravnom prometu. Naime, ranije u tekstu analizirana skupina pravila kojom se dopušta povrat zapravo obeshrabruje stjecatelje da stječu novac ili neku drugu stvar nemoralno, jer će se stečeno moći uspješno potraživati natrag. S druge strane, kad je nemoralan platitelj, sam ili zajedno sa stjecateljem, nemogućnost povrata njega također obeshrabruje da ulazi u bilo kakve nemoralne transakcije.

U tom smislu moglo bi se reći kako kondiciranje ob turpem rem po svojoj funkciji ima vlastiti raison d'être u rimskom pravnom sustavu, bez obzira na to što se po terminologiji i kategorizaciji u izvorima i u literaturi svrstava uz bok kondiciranju ob rem. Je li takva kategorizacija u potpunosti opravdana, te koje je zapravo bilo podrijetlo takvog kondiciranja i na koji način se ono uklapalo u opći rimski kondikcijski sustav, predmet je analize koja slijedi.

\subsection{Podrijetlo kondiciranja ob turpem rem i njegov položaj u općem rimskom kondikcijskom sustavu}

Već je ranije navedeno kako se u literaturi ob turpem rem condicere smatra samo iznimkom od kondiciranja ob rem. Tako se zbog nemoralnosti odudara od pravila da je povrat predanog u određenu svrhu moguć jedino ako se navedena svrha nije ispunila. Odnosno, kako je utvrđeno u prethodnom tekstu, ako postoji nemoralnost isključivo na strani stjecatelja, platitelj će moći kondicirati predano natrag čak i ako se svrha predaje ispunila. U pozadini navedenog objašnjenja može se naći tvrdnja kako su u rimskom klasičnom pravu zapravo postojale samo tri kondikcije, i to condictio indebiti, condictio ob causam finitam i condictio ob rem (Honsell, 1974, str. 66). Takva tvrdnja proizlazi u bitnom dijelu iz jednog Paulovog fragmenta, u kojem se navodi kako do svake predaje dolazi bilo ob transactionem (na temelju nagodbe), ob causam, propter condicionem (zbog uvjeta), ob rem ili ob indebitum (na temelju plaćanja neduga) (D. 12, 6, 65, pr. (Paul. 17 ad plaut.)). $\mathrm{U}$ istom fragmentu nadalje se objašnjava u kojim slučajevima je dopušten povrat, na čemu se zaista mogu konstruirati tri navedena oblika kondiciranja. Nadalje, isti pravnik Paul u D. 12, 5, 1, pr. (Paul. 10 ad sab.) navodi da do predaje može doći radi neke svrhe (ob rem) ili na nekom temelju (ob causam), a opet da svrha može biti časna ili nečasna, odnosno nemoralna: omne quod datur aut ob rem datur aut ob causam, et ob rem aut turpem aut honestam. Uz to, u nastavku fragmenta, u D. 12, 5, 1, 2 (Paul. 10 ad sab.) navodi se kako se ono što se primi na temelju koji je turpis može zahtijevati natrag, makar svrha bila izvršena (Quod si turpis causa accipientis fuerit, etiamsi res secuta sit, repeti potest). Na temelju navedenog i u literaturi se zaključuje kako je nemoralna svrha (turpis res) zapravo samo podvrsta predaje za određenu svrhu, te kako kondiciranje ob turpem rem nastupa tek ako nastupi predmetna radnja uz koju se vezuje isplata (recimo, neizvršenje ubojstva povodom prijetnje), dok je u protivnom dostupno kondiciranje ob rem (Honsell, 1974, str. 84). 
Međutim, ovdje je važno na pravilan način promatrati klasični rimski kondikcijski sustav u cjelini, u skladu s onim što je rečeno na samom početku. U tom smislu nije točno da je klasično pravo poznavalo samo tri kondikcije, dok su ostali slučajevi ili atipična iznimka, kakva bi bila condictio furtiva (Honsell, 1974, str. 66 bilj. 5) ili bizantinska interpolacija, što bi bila condictio ob turpem (vel iniustam) causam (Honsell, 1974, str. 81). Klasični rimski kondikcijski sustav trebali bismo promatrati kroz njegovo postupovno uređenje, koji je ključan za njegovo oblikovanje, a samim time i za njegovo pravilno shvaćanje. U svjetlu rečenog, sasvim je jasno kako je netočno da su postojale samo tri kondikcije kako se navodi u literaturi, nego kako je zapravo postojala samo jedna condictio u formularnom postupku i klasičnom pravu. Postojala je jedinstvena formula za condictio, a njena primjena u različitim slučajevima, očito, ovisila je o interpretaciji pravnika nadovezanoj na područje primjene legisakcije per condictionem. U tom smislu bi svi slučajevi primjene klasične kondikcije bili na ovaj ili onaj način povezani, odnosno postojao bi zajednički kriterij njene primjene.

U literaturi postoje opsežne rasprave o tomu što bi taj zajednički kriterij primjene trebao biti, i nema potrebe za ponavljanjem svega na ovome mjestu. Ugrubo, moglo bi se reći kako je središnji kriterij bio neopravdanost zadržanja određene imovine kod neke osobe ( $c f$. Schwarz, 1952, str. 303 sq.). Međutim, ovdje treba posebno naglasiti ulogu kondiciranja ob turpem rem u cijelom tom sustavu. Kako se može vidjeti u početnom dijelu ovoga teksta, područje primjene legisakcije per condictionem je od samoga početka usko vezano za određene delikte (furtum) odnosno čine srodne deliktima (navodno deliktno podrijetlo zajma), dakle svakako nemoralne čine. U tom svjetlu ne bi trebalo biti nimalo čudno ili izvanredno što se klasična condictio primjenjuje u određenim slučajevima koji se vezuju uz turpitudo. Kako se može vidjeti iz obavljene analize izvora, navedeni slučajevi su se ili odnosili na nemoralnu (eventualno i deliktnu) radnju ili je bila riječ o prijetnji da će se takva radnja poduzeti ako ne dođe do isplate. Turpitudo, odnosno res ili causa turpis kao temelj stjecanja sasvim nedvojbeno određeno zadržanje imovine mogu učiniti neopravdanim i pravno neprihvatljivim, a pritom su u skladu s izvornim područjem primjene kondikcijskih zahtjeva u njihovom najranijem obliku.

Također, zaključak kako je kondiciranje ob turpem rem samo podvrsta kondiciranja ob rem i kako nastupa jedino ako se predmetna radnja ispuni, jer je inače dostupno kondiciranje $o b$ rem, posljedica je pretjerano tehničkog iščitavanja spomenutih fragmenta D. 12, 5, 1, pr. i 2 (Paul. 10 ad sab.). Iz analiziranih slučajeva primjene kondiciranja ob turpem rem ranije u tekstu vidljivo je kako se kod njih condictio može upotrijebiti zbog same činjenice postojanja nemoralnosti koja se vezuje od određenu datio. Istina jest da je kod prijetnje da će se izostankom predaje novca ili drugih stvari izvršiti ubojstvo, sacrilegium, furtum i sl. neizvršenje po isplati zapravo res secuta. U tom smislu jedino je tada potrebno kondiciranje $o b$ turpem rem, a u protivnom je, navodi se, dostajala kondikcija ob rem (postklasična condictio causa data causa non secuta). Ali zapravo nigdje iz analiziranih fragmenata ne proizlazi da bi izvršenje navedenih djela (dakle, primjerice izvršenje zaprijećenog djela usprkos isplati) sprječavalo kondiciranje ob turpem rem. Po 
navedenim fragmentima, deliktne i nemoralne radnje uz koje se vezuje predaja novca ili neke druge stvari nisu morale biti izvršene da bi se omogućilo kondiciranje ob turpem rem. U kontekstu kondiciranja ob turpem rem, odnosno pod titulom condictio ob turpem vel iniustam causam u Digesta, navodi se isključivo kako sama predaja u kojoj je uključena nemoralnost na strani stjecatelja omogućuje povrat. Stoviše, ističe se kako može postojati turpitudo na strani platitelja ili stjecatelja (npr. u D. 12, 5, 3 (Paul. 10 ad sab.)), iz čega se vidi kako je ključni kriterij za omogućivanje ili sprječavanje kondiciranja postojanje ili nepostojanje nemoralnosti. $\mathrm{U}$ tom smislu kondikcija u navedenim slučajevima nastupa sasvim nevezano za to hoće li predmetna turpis radnja nastupiti ili ne, već je sama činjenica postojanja nemoralnosti glavni razlog za njenu upotrebu.

Paulova objašnjenja iz navedenih fragmenata, uopće ne ulazeći u pitanje njihove klasičnosti i autentičnosti, ne bi trebalo shvaćati kao definitivne i dogmatske stavove o kondikcijskom uređenju u klasičnom pravu. Moguće je da je Paulo, sam zapravo kasnoklasični autor ( $c f$. o tomu Honoré, 1962, xi i passim), samo sistematizirao pojedine slučajeve primjene klasične kondikcije na način koji mu se činio (i koji jest) sasvim logičan, bez da je uopće imao namjeru određivanja koncepta i uređenja kondikcijskih zahtjeva u cjelini. Svrha toga možda je bila didaktička, radi lakšeg shvaćanja i pamćenja nekog uređenja. Takva je primjerice bila situacija s određenim etimološkim objašnjenjima rimskih pravnika za koja je utvrđeno da nisu autentično definirala podrijetlo određenih termina i koncepata, nego da su bila sredstva za lakše pamćenje ili razumijevanje. ${ }^{11}$ Uzimanje u obzir nastanka i cjelokupnog razvoja kondikcijskih zahtjeva u rimskom pravu uvjetuje drukčije zaključke o kondikcijskim zahtjevima u klasičnom pravu općenito i specifično o kondiciranju ob turpem rem, nego što bi se dalo naslutiti površnim iščitavanjem klasičnih i postklasičnih izvora. U tom kontekstu ob turpem rem condicere nije iznimka ili podvrsta kondiciranja ob rem. Dapače, ono se može promatrati kao integralni i središnji primjer upotrebe klasične condictio, u skladu s temeljnim kriterijima njene primjene i izvorima kondikcijskih zahtjeva u legisakciji per condictionem.

\section{ZAKLJUČAK}

U radu se pristupilo analizi podrijetla i relevantnosti kondiciranja ob turpem rem uzimajući u obzir nastanak i razvoj kondikcijskih razvoja u cjelini. Na taj način nastojalo se reinterpretirati uobičajeno shvaćanje kondiciranja ob turpem rem, koje u bitnom dijelu počiva na plošnom analiziranju izvora Justinijanovog prava. Također, navedenom analizom pokušalo se sugerirati objašnjenje kondiciranja ob turpem rem u klasičnom pravu i kondikcije ob turpem (vel iniustam) causam u postklasičnom

11 Tako primjerice Gaj u Gai. Inst. III, 90 objašnjava podrijetlo riječi mutuum, te navodi kako ime ovog instituta dolazi od toga što on nastaje time što ono je moje (meum) postaje tvoje (tuum). Međutim, ovo se nedvojbeno smatra pseudoetimologijom ( $c f$. Jörs et al., 1987, str. 297; Zimmerman, 1992, str. 153, $\mathrm{s}$ uputama na daljnju literaturu). Različite funkcije etimologije klasičnih pravnika predmet su analize $\mathrm{u}$ Babusiaux, 2014. 
u Justinijanovom pravu u skladu s izvornim područjem primjene legisakcije per condictionem. Ovakvim pristupom nastojalo se izbjeći rašireno tumačenje navedene problematike koje se u pravilu vezuje uz pojavnu strukturu condictio ob turpem (vel iniustam) causam kod Justinijana uz eventualne izlete u problematiku autentičnosti pojedinih fragmenata ili njihovih elemenata.

Navedeni pristup zahtijeva promjenu perspektive na predmetnu problematiku, bolje rečeno promjenu paradigme. U toj vizuri kondikcijski zahtjevi u rimskom pravu promatraju se kao jedna cjelina koja je nastala i razvijala se u trima različitim postupovnim sustavima. Riječ je o legisakcijskom postupku per condictionem, jedinstvenoj formularnoj condictio klasičnog prava koja je imala niz različitih instanci primjene te naposljetku različitim condictiones postklasičnog i Justinijanovog prava. U toj razvojnoj cjelini postoji jedna opća poveznica koja se na različite načine manifestirala u pojedinim razvojnim ciklusima, koja bi se mogla svesti na neopravdanost zadržanja novca ili drugih stvari kao temeljni kriterij primjene bilo kojeg kondikcijskog zahtjeva. Ali najvažnije za predmetnu analizu, od izvornog i najstarijeg uređenja kondikcijskih zahtjeva, legisakcije per condictionem, pa sve do fiksiranja kondikcijskog uređenja kod Justinijana, u samoj biti tih zahtjeva uvijek su bile prisutne određene radnje vezane uz turpitudo, odnosno radnje turpis. Tako se legis actio per condictionem primjenjivala u slučajevima krađe (furtum), odnosno zajma (mutuum), vezano za što je bitno istaknuti teoriju o njegovom deliktnom podrijetlu. U smislenom nadovezivanju, tipologija primjene kondikcije u klasičnom pravu također svjedoči o upotrebi tog sredstva u nizu situacija koje se odnose na delikte, infamirajuce radnje, a u svakom slučaju radnje koje podrazumijevaju turpitudo. U skladu s općim društvenim i pravnim razvojem klasičnog prava, turpitudo je bila kategorija koja se odnosila na različite standarde ponašanja, koji su se mogli mijenjati običajima ili intervencijama pravnika ili carskog dvora. Ali u svakom slučaju time se nije nimalo smanjivala veza s izvornim područjem primjene legisakcije per condictionem.

$\mathrm{U}$ tom smislu kondiciranje ob turpem rem je u cjelokupnom svojem razvoju unutar rimskog prava ostalo sasvim u skladu s općim kriterijima i izvornom primjenom kondikcijskih zahtjeva. Zbog toga se nikako ne bi trebalo smatrati atipičnim primjerom odnosno varijacijom ili iznimkom od kondiciranja ob rem, što je česta kategorizacija u literaturi. Kasnoklasični izvori koji daju potporu takvom stavu mogu se objasniti kao didaktički i sistematizacijski pokušaji objašnjavanja postojećeg prava, koji nikad nisu ni imali ambiciju sveobuhvatnog sistematiziranja kondikcijskih zahtjeva u rimskom pravu, uključujući i njihov povijesni razvoj. U svakom slučaju, navedeni pristup problematici kondiciranja ob turpem rem zacijelo je ključan radi pravilnijeg shvaćanja i kondikcijskih zahtjeva u rimskom pravu u cjelini kao i njihove naknadne srednjovjekovne obrade i recepcije u suvremene pravne poretke. 


\section{LITERATURA}

1. Albanese, B. (1987). Il processo privato romano delle legis actiones. Palermo: Palumbo.

2. Babusiaux, U. (2014). Funktionen der Etymologie in der Juristischen Literatur. Fundamina 20 (1), 39-60.

3. Betti, E. (1966). Processo civile (diritto romano). U Azara, A., Eula, E. (ur.), Novissimo Digesto Italiano, vol. 13 (1099-1120). Torino: UTET.

4. Buckland, W. W., Stein, P. (1966). A Text-Book of Roman Law from Augustus to Justinian. Cambridge: CUP.

5. Cannata, C. A. (1970). Sulla "divisio obligationum" nel diritto romano repubblicano e classico. IVRA: rivista internazionale di diritto romano e antico XXI, 52-70.

6. Cannata, C. A. (1980). Profilo istituzionale del processo privato romano, vol. 1. Torino: Giappichelli.

7. Cannata, C. A. (1982). Profilo istituzionale del processo privato romano, vol. 2. Torino: Giappichelli.

8. Cange, D. du (1887). Glossarium mediae et infimae latinitatis, vol. 8. Niort: L. Favre.

9. Chaudet, F. (1973). Condictio causa dana causa non secuta. Lausanne: Imprimerie Vaudoise.

10. Daube, D. (1986). Turpitude in Digest 12.5.5. U Bagnall, R. S., Harris W. V. (ur.), Studies in Roman Law in Memory of A. Arthur Schiller (33-38). Leiden: E. J. Brill.

11. Eisner, B. i Horvat, M. (1948). Rimsko pravo. Zagreb: Nakladni zavod Hrvatske.

12. Falcon, A. (2012). Aristotle on Causality. Dostupno na http://plato.stanford.edu/ archives/spr2014/entries/aristotle-causality/.

13. Forcellini, E. (1940). Lexicon totius latinitatis, vol. 4. Padova: Typis seminarii.

14. Gamauf, R. (2002). Turpitudo. U Cancik, H., Schneider, H. (ur.), Der neue Pauly: Enzyklopädie der Antike, vol. 12, 1 (927-928). Stuttgart: JB Metzger.

15. Guarino, A. (2001). Diritto privato romano. Napoli: Jovene.

16. Held, H.-R. (2015). Nastanak i razvoj modela kondikcijske zaštite u rimskoj pravnoj tradiciji. (Neobjavljena doktorska disertacija). Pravni fakultet Sveučilišta u Zagrebu: Zagreb.

17. Held, H.-R. (2017). Podrijetlo postupka legis actio per condictionem. Zbornik Pravnog fakulteta u Zagrebu 67 (2), 197-227. Dostupno na https://hrcak.srce.hr/ index.php?show=clanak\&id_clanak_jezik=267734.

18. Honoré, T. (1962). Gaius. Oxford: Clarendon Press.

19. Honsell, H. (1974). Die Rückabwicklung sittenwidriger oder verbotener Geschäfte. München: CH Beck.

20. Jörs, P., Kunkel, W., Wenger, L. (1987). Römisches Recht. Berlin: Springer.

21. Karlović, T. i Held, H.-R. (2011). Stjecanje na temelju nemoralne ili nedopuštene osnove. Informator: instruktivno-informativni list za ekonomska i pravna pitanja 5975, 8-9. 
22. Kaser, M. (1939). Mores maiorum und Gewohnheitsrecht. Zeitschrift der SavignyStiftung für Rechtsgeschichte: Romanistische Abteilung 59 (1), 52-101.

23. Kaser, M. (1940). Rechtswidrigkeit und Sittenwidrigkeit im klassischen römischen Recht. Zeitschrift der Savigny-Stiftung für Rechtsgeschichte: Romanistische Abteilung 60 (1), 95-149.

24. Kaser, M. (1961). Das Geld im römischen Sachenrecht. Tijdschrift voor Rechtsgeschiedenis 29 (2), 169-229.

25. Kaser, M. (1967). Römische Rechtsgeschichte. Göttingen: Vandenhoeck \& Ruprecht.

26. Kaser, M. (1971). Das römische Privatrecht I. Das altrömische, das vorklassische und das klassische Rect. München: CH Beck.

27. Kaser, M. (1975). Das römische Privatrecht II. Die nachklassischen Entwicklungen. München: CH Beck.

28. Kaser, M. (1977). Über Verbotsgesetze und Verbotswidrige Geschäfte im römischen Recht. Wien: Verlag der ÖAW.

29. Kaser, M. i Hackl, K. (1996). Das römische Zivilprozessrecht. München: CH Beck.

30. Klarić, P. i Vedriš, M. (2006). Građansko pravo. Zagreb: Narodne novine.

31. Lewis, C. T. i Short, C. (1879). A Latin Dictionary. Oxford: OUP. Dostupno na http:// www.perseus.tufts.edu.

32. Liebs, D. (1972). Die Klagenkonkurrenz im römischen Recht. Göttingen: Vandenhoeck \& Ruprecht.

33. Liebs, D. (1978). Bereicherungsanspruch wegen Mißerfolgs und Wegfall der Geschäftsgrundlage. Juristenzeitung 33 (21), 697-703.

34. Liebs, D. (1986). The History of the Roman Condictio up to Justinian. U MacCormick, N., Birks, P. (ur.), The Legal Mind. Essays for Tony Honoré (163-183). Oxford: Clarendon Press.

35. Luzzatto, G. I. (1946). Procedura civile romana, vol. 3. Bologna: Edizioni Universitarie.

36. Magdelain, A. (1991). Naissance de la procédure formulaire. Tijdschrift voor Rechtsgeschiedenis 3-4, 239-257.

37. Mantovani, D. (1999). Le formule del processo privato romano. Padova: CEDAM.

38. Mayer-Maly, T. (1969). Legis actio. U Ziegler, K., Sontheimer, K. (ur.), Der kleine Pauly: Lexikon der Antike, vol. 3 (546-547). Stuttgart: Alfred Müller.

39. Medicus, D. (1975). Turpitudo. U Ziegler, K., Sontheimer, K. (ur.), Der kleine Pauly: Lexikon der Antike, vol. 5 (1009). Stuttgart: Alfred Müller.

40. Nicosia, G, (1986), Il processo privato romano, vol. 1. Torino: Giappichelli.

41. Nikšić, S. (2012). Kauza obveze i srodni instituti u poredbenom pravu. Zbornik Pravnog fakulteta u Zagrebu 56 (4), 1057-1102. Dostupno na https://hrcak.srce.hr/ index.php?show=clanak\&id_clanak_jezik=8211.

42. Paulus, C. G. (1999). Legis actio. U Cancik, H., Schneider, H. (ur.), Der neue Pauly: Enzyklopädie der Antike, vol. 7 (22-24). Stuttgart: JB Metzger.

43. Pika, W. (1988). Ex causa furtiva condicere im klassischen römischen Recht. Berlin: Duncker \& Humblot. 
44. Provera, G. (1989). Lezioni sul processo civile giustinianeo I-II. Torino: Giappichelli.

45. Pugliese, G, (1961), Il processo civile romano, vol. 1. Roma: Ricerche.

46. Raber, F. (1964). Condictio. U Ziegler, K., Sontheimer, W. (ur.), Der kleine Pauly, Lexikon der Antike, vol. I (1272-1273). Stuttgart: Alfred Druckenmüller.

47. Raber, F. (1969). Mutuum. U Ziegler, K., Sontheimer, W. (ur.), Der kleine Pauly, Lexikon der Antike, vol. III (1502-1503). Stuttgart: Alfred Druckenmüller.

48. Rotondi, G. (1962). Leges publicae populi romani. Hildesheim: Olms.

49. Sachers, E. (1948). Turpitudo. U Wissowa, G., Kroll, W. (ur.), Paulys RealEncyklopädie der classischen Altertumswissenschaft, zweite Reihe, vol. 7, 2 (14321439). Stuttgart: JB Metzger.

50. Scherillo, G. (1969). La "legis actio per iudicis arbitrive postulationem" e le origini del processo formulare. IVRA: rivista internazionale di diritto romano e antico XX, $5-48$.

51. Schwarz, F. (1952). Die Grundlage der condictio im klassischen römischen Recht. Köln: Böhlau.

52. Simon, D. (1969). Untersuchungen zum Justinianischen Zivilprozeß. München: CH Beck.

53. Sturm, F. (1986). Quod meretrici datur repeti non potest. U Benöhr, H.-P., Hackl, K., Knütel, R., Wacke, A. (ur.), Iuris professio. Festgabe für Max Kaser zum 80. Geburtstag (281-288). Wien: Böhlau.

54. Talamanca, M. (1987). Processo civile (diritto romano). U Moratti, C., Pugliatti, S. (ur.), Enciclopedia del diritto, vol 36 (1-79). Milano: Giuffrè.

55. Tredennick, H. (1989). Aristotle, Metaphysics, books I-IX. Cambridge: HUP.

56. Weiss, E. (1925). Legis actio. U Wissowa, G., Kroll, W. (ur.), Paulys RealEncyklopädie der classischen Altertumswissenschaft, erste Reihe, vol. 12, 2 (18381842). Stuttgart: JB Metzger.

57. Zimmerman, R. (1992). The Law of Obligations. Roman Foundations of the Civilian Tradition. Cape Town: Juta \& Co Ltd. 


\section{CONDICTIONAL CLAIMS AND TURPITUDO IN ROMAN LAW}

The author analyses condictional claims (claims associated with condictio) in Roman law, in which turpitudo, or immorality, was involved in certain way. Firstly he analyses these claims in three different Roman procedural systems, legis actio per condictionem, condictio of the formulary procedure and different condictiones of the postclassical and Justinianic law and cognitio extraordinaria. Afterwards, the meaning of turpitudo and turpis in Roman law is discussed. In the central part of the text the author deals specifically with the typology of the instances of ob turpem rem condicere in the sources, in other words he analyses condictio ob turpem (vel iniustam) causam from the Justinian's codification. Analysing the extant literature on the matter, finally he gives a reinterpretation regarding main functions of the ob turpem rem condicere in Roman law, while suggesting a possible explanation of its origins and its consequent relevance in the general Roman condictional system.

Key words: condictional claims, condictio, turpitudo, condictio ob turpem vel iniustam causam, Roman law 